\title{
The future of coastal ecosystems: learning from Venice
}

\author{
Sandro Pignatti · Giovanni Seminara
}

Published online: 27 June 2009

(C) Springer-Verlag Italia 2009

Venice and its lagoon have survived throughout the centuries due to continuous human actions aimed at maintaining a dynamic equilibrium between the two major opposing forces, land and water, threatening this delicate environment. Two coordinated symposia, organised by the Accademia Nazionale dei Lincei ${ }^{1}$ and the Istituto Veneto di Scienze, Lettere ed $\mathrm{Arti}^{2}$ were a welcome opportunity for a general overview on the environmental and social problems of this unique town. Lectures pointed out how the recent history of Venice may be regarded as an example of a much broader problem: the future of coastal ecosystems on alluvial substrates directly exposed to the climatic change. As a consequence, the issue under discussion can be widened from a problem of local interest (although with major social, economic and cultural evidence) to a potential threat for many of the most densely populated areas of the Earth.

During the long history of Venice, a number of soft or more substantial interventions became necessary. Most notably, amongst the latter, those pursued by the Venice Republic to preserve its 'marine' vocation, namely the diversion of entire major rivers debouching into the lagoon (XII-XIV century $\mathrm{AD}$ ) and the construction of sea defences (the 'murazzi', in 1738). The industrial revolution in the XIX century, with the development of steam navigation, forced a number of further substantial interventions, like the narrowing of inlets with the construction of long jetties protruding into the sea. In the period 1920-1930, a new extended industrial pole was reclaimed at the boundary of the lagoon (Porto Marghera); after World War II the plants were reconstructed and the total area further

1 "The safeguard of Venice and its lagoon": Rome, June 5, 2008: Environment Day in honour of Enrico Marchi (1925-2007).

2 "Venice_Image, reality, future and problems": Venice, November 6-7 (2008).

\footnotetext{
S. Pignatti $(\bowtie)$

Dipartimento di Biologia Vegetale, Università di Roma "La Sapienza", Città Universitaria, P.le A. Moro 5, 00185 Rome, Italy

e-mail: pignatti@lincei.it

G. Seminara

Dipartimento di ingegneria delle costruzioni, dell'ambiente e del territorio (DICAT), Università degli Studi di Genova, Via Montallegro, 1, 16145 Genoa, Italy

e-mail: giovanni.seminara@unige.it
} 
expanded: presently it largely exceeds the total surface of the city of Venice. The conspicuous investments for this task were justified by the necessity to qualify Venice as a major partner in the industrial economy. At its peak the production involved ca 30,000 workers, but presently many activities are dismissed and the total declined by a factor of three. A heavy inheritance remains: a large area of polluted soil in the plant and at the bottom of the lagoon. After the excavation of the deep channel at the southern edge (Canale dei Petroli), the central lagoon has undergone a process of progressive deepening that tends to transform its very nature. Finally, sea level rise and subsidence (both natural and anthropogenic) have affected the liability of Venice to high waters and the morphological evolution of its lagoon. As a result, two major problems have emerged: on the one hand, Venice is inundated much more often than it used to be at the beginning of the last century; on the other, a large part of the salt marshes, unique environments hosting a great deal of biodiversity, have disappeared.

The former problem had dramatic consequences with the exceptional high water of November $1966(1.94 \mathrm{~m})$, when the whole city was submerged for $19 \mathrm{~h}$ and the sea defences were locally disrupted. The (admittedly slow) response of the Italian governments was to produce a complex ad hoc legislation that was based on the decision to attribute national relevance to the issue of Venice. One of the by products of this legislation was to provide support to systematic research activities, which made Venice lagoon one of the best known and monitored ecosystems in the world.

The mechanics of tide propagation throughout the lagoon is now well known, and a great deal of investigations has been able to clarify the actual causes responsible for the increased frequency of exceptionally high tides. There is now a fairly general consensus that the latter phenomenon is due to the combined effects of sea level rise and subsidence amounting to $23 \mathrm{~cm}$ in the last century. This conclusion has definitely removed the basis of the strong debate, raised by the green movement, on the possible role played by the construction of the new Canale dei Petroli, the closure of fish ponds and land reclamation works. It has been established that they have played virtually no role in the enhanced phenomenon of high water.

Indeed, the construction of the channel was followed by a unforeseen erosion in the central portion of the lagoon. Investigations have also clarified what degree of protection Venice can be granted through the various types of interventions envisaged by the scientific community over the past four decades. There is again a fairly general consensus on the conclusion that feasible solutions include the temporary (partial or total) closure of the inlets, coupled with island confinement and increase in the elevation of the lower parts of the city. All these solutions are being simultaneously pursued through a vast programme of works in progress: in particular, a significant part of the works needed to lay down the mobile gates at the inlets has been completed. Whether or not inlets should have also been partially restricted through fixed works has been a further source of constant debate. The ultimate decision confirmed previous conclusions, namely that the small advantages of permanent inlet narrowing would not justify the significant disadvantages associated with a non-negligible reduction of the natural exchange of water between the lagoon and the sea. This decision was reached by the Italian government in 2006, although not unanimously.

A number of new and interesting problems will arise when the defence works will be completed. They are related to the choice of optimal management procedures for the mobile gates in order to minimise obstacles to navigation and possibly enhance beneficial secondary circulations in the lagoon. These issues may become increasingly important depending on how severe the sea level rise will be in the present century. It has to be pointed out that Venice is a unique example from the social and cultural point of view. 
Moreover, the ecosystem of Venice lagoon, with the plants and animals occurring on its shores and salt marshes are the expression of a complex postglacial development (Bonatti 1968; Pignatti 1960, 1962, 1966).

Although the issue of defending Venice from exceptional tides appears to have finally found a solution valid for the lifetime of an engineering project (which is of the order of one century), in contrast the problem of ensuring that the ecosystem of Venice will continue playing its important physical, biological and cultural role is far from being solved. Several observations support this statement. The lagoon morphology is evolving rapidly due to the enhanced erosion of shoals and salt marsh degradation. To what extent this process has been accelerated by the construction of the Canale dei Petroli will have to be ascertained. The natural environment of the littoral barriers has suffered from the effects of further urbanisation. Many of the most significant components of the biological heritage are at a risk of extinction, while allochthonous species are spreading increasingly. Finally, industrial and domestic pollution have worsened considerably in the last century.

Some activities aimed at reversing the above trends have indeed been undertaken in the last few decades. This applies in particular to the successful confinement of polluted wastes within controlled areas and the ongoing partial reconstruction of artificial salt marshes employing fine sediments resulting from periodic dredging of channels undergoing siltation.

Notwithstanding, a number of further issues remain to be open. They call for a shift of attention in two directions.

The former direction concerns lagoon ecology. First, thoroughly interdisciplinary research is called for in order to fully understand the mechanisms of morphological degradation, a condition required in order to continue the process of marsh reconstruction that needs to be further pursued in the future. Ecology and engineering will have to enhance their dialogue. This is becoming more important with the threat of climate change and enhanced sea level rise. A number of major issues arise in this respect: to what extent are salt marshes able to keep up with sea level rise? How dependent is this process on the supply of mineral sediments and the production of organic sediments through biomass growth-degradation? Will this lead to a change in the vegetation patterns? Can we oppose these tendencies by reintroducing river sediments in the lagoon? How would such a decision affect water quality and would it produce sanitary problems? Moreover, the management of the biological heritage in protected areas needs be carefully planned. Finally, the process of water quality improvement will have to be continued and enhanced, while contaminated sites will need to be decontaminated in order to be made amenable to appropriate reuse.

A second major issue concerns the socioeconomic evolution of the Venetian territory. In fact, a strong emigration of the population towards the mainland has been recently experienced, while the industrial activities of Marghera have significantly declined. Presently, the total population in the historical town is rapidly decreasing $(62,000$, as opposed to 176,000 on the mainland-data 2006). The historical centre of the city has lost part of its traditional features, while economic activities have progressively shifted more and more towards tourism. Will the latter development of the urban-lagoon system be sustainable from the environmental and social points of view? A sound condition can be restored only in the frame of a credible hypothesis of economical development. Regulation and integration of tourism with other economic activities of the city are called for and, in order to pursue these aims, entrepreneurial activities of the post-industrial sector involving qualified human capital should be attracted. If this should not happen, the success in the hydrological regulation of the basin will not be sufficient to prevent the irreversible decline of Venice and its ecosystem. 
A last important challenge is left to the scientific community. It concerns the vast amount of knowledge built on the issue of Venice in the last few decades: this knowledge must not be dispersed. In contrast, its paradigmatic significance for the widespread issue of the impact of climate change on similar coastal ecosystems throughout the world, should be valued: possibly locating in Venice a strongly interdisciplinary International Centre for Coastal Ecosystems and Climate Change, devoted to the investigation of the variety of problems raised by the need to make the ecological preservation of coastal ecosystems compatible with their great economic value.

Rendiconti Lincei would like to stress the importance of the problem of Venice, considered from the physical, environmental, biological and cultural points of view, and on the possibility to exchange experiences dealing with similar ecosystems in other coastal regions of the world. A Focus will be opened under the title "The future of coastal ecosystems-Learning from Venice" and maintained during 2009-2010.

A general analysis of the results, after 40 years of activity, shows that the control of high water and the consolidation of sea defences have found a solution, while lagoon ecology and the socioeconomic evolution of Venice open entirely new problems. The recent evolution of the lagoon can indeed be considered as a case study within the more general issue of the safeguard of coastal regions threatened by the rise of sea level.

The international scientific community is kindly invited to submit papers dealing with theory, data analysis, experimental results or discussions of case studies. These papers will be submitted for publication in Rendiconti Lincei as a first contribution on a local problem, which in the future will attain global interest.

Sandro Pignatti, Giovanni Seminara

\section{References}

\section{Selected bibliographic sources}

AA various (2006) Atlante della laguna-Venezia tra terra e mare. Comune di Venezia

\section{Tide forecasting}

Tomasin A (2005) Forecasting the water level in Venice: physical background and perspectives. In: Fletcher CA, Spenser T (eds) Flooding and environmental challenges for Venice and its Lagoon: state of knowledge. Cambridge University Press, Cambridge, pp 71-78

\section{Subsidence}

Bonatti E (1968) Late Pleistocene and postglacial stratigraphy of a sediment core from the Lagoon of Venice, Italy. Mem di Biogeogr Adriat 7, 1

Bortolami G, Carbognin L, Gatto P (1984) The natural subsidence in the Lagoon of Venice, Italy. In: A, I Johnson et al (eds) IAHS Publication n 151, Land Subsidence. Oxfordshire, pp 777-784

Camporese M, Gambolati G, Putti M, Teatini P (2006) Peatland subsidence in the Venice watershed. In: Martini et al (eds) "Peatlands: basin evolution and records on global environmental and climatic changes", Chap 23, I.P., Elsevier, Amsterdam, pp 529-550

Carbognin L, Gatto P (1981) The lagoon of Venice: natural environmental trend and man-induced modification. Hydrol Sci Bull 26:379-391 
Carbognin L, Marabini F, Tosi L (1995) Land subsidence and degradation of the Venetian littoral. In: Barends F et al (eds) Land subsidence, IHAS Publication 234, Balkema, pp 391-402

Carbognin L, Taroni G (1996) Eustatismo a Venezia e Trieste nell'ultimo secolo. Atti Ist Ven Sc Lett Arti 154

Carbognin L, Teatini P, Tosi L (2004) Eustasy and land subsidence in the Venice Lagoon at the beginning of the new millennium. J Mar Syst 51(1-4):345-353. doi:10 1016/j jmarsys 200405021

Carbognin L, Tosi L (2002) Interaction between climate changes, eustacy and land subsidence in the North Adriatic Region, Italy. Mar Ecol 23(1):38-50

Castelletto N, Ferronato M, Gambolati G, Putti M, Teatini P (2008) Can Venice be raised by pumping water underground? A pilot project to help decide. Water Resour Res 44

Comerlati A, Ferronato M, Gambolati G, Putti M, Teatini P (2003) Can $\mathrm{CO}_{2}$ help save Venice from the sea? EOS Trans Am Geophys Union 84(49):546-553

Gambolati G, Freeze RA (1973) Mathematical simulation of the subsidence of Venice. 1-Theory. Water Res Resour 9(3):721-733

Gambolati G, Gatto P, Freeze RA (1974) Mathematical simulation of the subsidence of Venice. 2-Results. Water Res Resour 10(3):563-577

Gambolati G et al (2005) Peatland oxidation enhances subsidence in the Venice watershed. EOS Trans Am Geophys Union 86(23):217-224

Gambolati G, Putti M, Teatini P, Gasparetto Stori G (2006) Subsidence due to peat oxidation and impact on drainage infrastructures in a farmland catchment south of the Venice lagoon, 1st International Conference on Groundwater in Geological Engineering, Bled (Slovenia), September 22-26, 2003. Environ Geol 49(6):814-820

\section{Hydrodynamics}

Blondeaux P, Seminara G, Vittori G (1993) Linear response of the gate system for protection of the Venice Lagoon. Rend Mat Accad Lincei 4:291-298 ibid. 299-305

D'Alpaos L, Defina A (1993) Venice lagoon hydrodynamic simulation by coupling 2D and 1D finite elements models. VII International Conference on Finite Elements in Fluids, Barcelona

Marchi E (1986) Valutazione della velocità nelle bocche lagunari. Atti del XX Convegno di Idraulica e Costruzioni Idrauliche, p 231

Vittori G (1997) Oscillating tidal barriers and random Waves. J Hydraulic Eng 406-412

Vittori G, Blondeaux P, Seminara G (1996) Waves of finite amplitude trapped by oscillating waves. Proc R Soc Ser A Lond 45L:791-811

\section{Venice defence}

Marchi E (1990) Sulla stabilità delle bocche lagunari a marea. Rend Fis Acc Lincei 9(1):137-150

Marchi E (1997) Venice and Florence: a complex dialogue with water. Symposium ITCOLD, Firenze

Marchi E (2003) La difesa di Venezia dalle acque alte. Atti Ist Ven Sc Lett Arti, Tomo 161

\section{Morphodynamics}

Defina A, Carniello L, D’Alpaos L, Fagherazzi S (2007) Spatial organization of shallow tidal lagoons in tidal flats and salt marshes. J Geophys Res. doi:10 1029/2006JF000550

Lanzoni S, Seminara G (2002) Long-term evolution and morphodynamics equilibrium of tidal channels. J Geophys Res 107(C1), 3001. doi:10 1029/2000JC000468

Mudd SM, Fagherazzi S, Morris JT, Furbish DJ (2004) Flow, sedimentation, and biomass production on a vegetated salt marsh in South Carolina: toward a predictive model of marsh morphologic and ecologic evolution. In: Fagherazzi S, Marani M, Blum L (eds) The ecogeomorphology of salt marshes, coastal and estuarine stud. vol 59. AGU, Washigton DC, pp 165-188

Tambroni N, Bolla Pittaluga M, Seminara G (2005) Laboratory observations of the morphodynamic evolution of tidal channels and tidal inlets. J Geophys Res 110:F04009. doi:10 1029/2004JF000243

Tambroni N, Seminara G (2006) Are inlets responsible for the morphological degradation of Venice Lagoon? J Geophys Res 111:F03013. doi:10 1029/2005 JF000334 


\section{Salt marshes and sea level rise}

van de Koppel J, van der Wal D, Bakker JP, Herman PMJ (2005) Self-organization and vegetation collapse in salt marsh ecosystems. Am Nat 165(1)

Morris JT (1995) The mass balance of salt and water in intertidal sediments: results from North Inlet, South Carolina. Estuaries 18:556-567

Morris JT (2000) Effects of sea level anomalies on estuarine processes. In: Hobbie J (ed) Estuarine science: a synthetic approach to research and practice. Island Press, pp 107-127

Morris JT, Sundareshwar PV, Nietch CT, Kjerfve B, Cahoon DR (2002) Responses of coastal wetlands to rising sea level. Ecology 83:2869-2877

\section{Pollution}

Blondeaux P, De Bernardinis B, Seminara G (1982) Correnti di marea in prossimita ' di imboccature e loro influenza sul ricambio lagunare. Atti XVIII Convegno di Idraulica e Costruzioni Idrauliche, Bologna, Italy, Sept 21-23

Gambaro A, Manodori L, Barbante C, Moret I, Capodaglio G, Cescon P (2004) Atmospheric aerosol concentration of Polychlorobiphenyls and Polycyclic aromatic hydrocarbons in the Venice Lagoon Analyt. and Bioanalyt. Chemistry 378:1806-1814

Rossini P, Guerzoni S, Molinaroli E, Rampazzo G, De Lazzari A, Zancanaro A (2005) Atmospheric bulk deposition to the lagoon of Venice: part I fluxes of metals, nutrients and organic contaminants. Environ Int 31:959-974

\section{Biology}

Amos CL, Bergamasco A, Umgiesser G, Cappucci S, Cloutier D, DeNat L, Flindt M, Bonardi M, Cristante S (2004) The stability of tidal flats in Venice Lagoon: the results of in situ measurements using two benthic, annular flumes. J Mar Syst 51:211-241

Cecconi G, Cerasuolo C, Barusolo G, Libardo S (2000) Bio-stabilization of the Venice lagoon tidal flat. SedNet Symposium "Sediment key-issues between the river and the sea", Venezia 24 Nov 2006

Comaschi A (1972) Studio sulla biomassa zooplanctonica nella Laguna di Venezia Atti Ist Ven Sc Lett Arti 140:117-146

D’Alpaos A, Lanzoni S, Marani M, Bonometto A, Cecconi G, Rinaldo A (2007) Spontaneous tidal network formation within a constructed salt marsh: observations and morphodynamic modelling. Geomorphology 91(3-4):186-197

Marchesoni V (1954) Il trofismo della laguna veneta: variazioni del fitoplancton. Arch Oceanogr Limnol 9:133-285

Pignatti S (1960) Ricerche sull'ecologia e sul popolamento delle dune del litorale di Venezia. Il popolamento vegetale. Bull Mus Civ St Nat Venezia 12:61-142

Pignatti S (1962) Associazioni di alghe marine sulle coste veneziane. Mem Ist Ven Sc Lett Arti 32(3):1-134

Pignatti S (1966) La vegetazione alofila della Laguna Veneta. Mem Ist Ven Sc Lett Arti 33(1):1-174

Pranovi F, Giovanardi O (1994) The impact of hydraulic dredging for short-necked clams, Tapes spp. on a faunal community in the Lagoon of Venice. Sci Mar 58:345-353

Socal G (1979) Nota sulla distribuzione quantitativa del fitoplancton nel bacino settentrionale della Laguna di Venezia. Rapp Studi, 8:105-119

Socal G, Boldrin A, Bianchi F (1985) Ciclo annuale e diversità del fitoplancton nel Porto di Malamocco, Laguna di Venezia. Atti Ist Ven Sc Lett Arti 14:15-30

Sorokin Y (1975) Seasonal changes in microplankton of the Venetian Lagoon. J Gene Biol (Moscow) 36:716-724 (in Russian)

Sorokin Y, Sorokin P, Giovanardi O, Dalla Venezia L (1996) Study of the ecosystems of the Lagoon of Venice, with emphasis on anthropogenic impact. Mar Ecol 141:247-271 